\title{
Climate change impacts and fungal decay in vulnerable historic structures at Svalbard
}

\author{
Anne-Cathrine Flyen ${ }^{1,2 *}$, Cecilie Flyen ${ }^{2,3}$, and Johan Mattsson ${ }^{4}$ \\ ${ }^{1}$ Norwegian institute for Cultural Heritage Research, Building Department, PB 736 Sentrum, 0105 Oslo, Norway \\ ${ }^{2}$ Norwegian University of Science and Technology, Faculty of Architechture and Design, Alfred Getz v. 3, 7491 Trondheim, Norway \\ ${ }^{3}$ SINTEF Community, Architectural Engineering, PB 124 Blindern, 0314 Oslo, Norway \\ ${ }^{4}$ Mycoteam AS, PB 5 Blindern, 0313 Oslo, Norway
}

\begin{abstract}
This paper emphasises on degradation of wood in cultural heritage structures at Svalbard. Nowhere else does global heating occur faster. Negative impacts of climate change will increase the strain on wooden structures and can daily be observed at Svalbard. The severe changes affect the degradation rate of wooden constructions, including cultural heritage. Certain microclimates, also in Polar areas, are favourable to fungal growth and decay. The probable enhancing effects climate change have on fungal degradation in wooden structures are however alarming. The paper displays findings of measurements from four different case study projects at Svalbard between 2009 and 2019. The results have been analysed separately, compiled and discussed in context, and towards relevant literature. We claim that impacts of climate change may not be generalized in order to predict effects in building materials. Further, that with extended knowledge on how climate change affects natural development of fungal decay, negative impacts may be reduced. Lessons learned from high Arctic areas might add longevity and sustainability to wooden cultural heritage constructions, also in different areas and environments. The paper is part of two of the authors' $\mathrm{PhD}$ work at the Norwegian University of Science and Technology.
\end{abstract}

\section{Introduction}

\subsection{Scope}

The UN Sustainable Development Goals (UN SDGs) [1] stresses the necessity of using renewable and sustainable resources for production of construction materials. Further, the UN SDG's highlights the need to protect cultural heritage and cultural environments. With an emphasis on case studies at Svalbard, the paper deals with degradation of wood in cultural heritage sites in Polar climates. How may climate change impacts affect the strain of wooden structures? Can insights and transfer values from the performed research be utilized in other climate zones and areas?

At Svalbard, the severe changes to the climate directly affect the degradation rate of wood materials in constructions, including cultural heritage. The use of wood as a building material has long traditions in the Nordic countries. Technical solutions have been adapted due to actual microclimatic exposure and local climatic conditions. Traditionally, wood constructions in Norway were mainly employed for smaller constructions, from the ancient Viking ships and stave churches, up to our era's small, individual houses [2]. At the end of the 1980s, new and affordable constructions and solutions for the use of wood in multi-storey buildings were gaining increasing attention, encouraged by experiences from the USA and
Canada. There, wooden houses have been built for up to six and seven floors for decades [3].

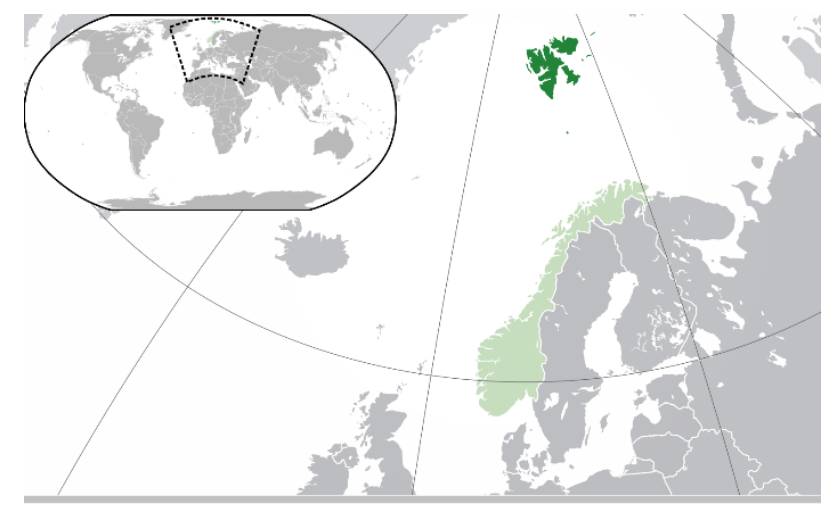

Fig.1. Map displaying mainland Norway and the Polar Archipelago of Svalbard (green). By Rob984 - Derived from File: Location European nation states.svg, CC BY-SA 4.0

The present focus on emission reduction and environmentally friendly building materials has revitalized timber as a construction material. Much due to its sustainable capacities, wood is increasingly used in larger constructions in Norway as well, and the use is trending towards even higher buildings, with wood also in load-bearing structures [3]. Also, because it is locally produced and processed, and as a renewable and carbonstoring material, wood is an important building material

\footnotetext{
* Corresponding author: anne.flyen@niku.no
} 
for housing, infrastructure, commerce and industry in Norway, including the Polar Archipelago of Svalbard $[4,5]$.

Buildings have been erected at Svalbard since the second part of $19^{\text {th }}$ century. The local building style was strongly affected by the harsh Polar climate with low average temperatures, permafrost and limited precipitation, combined with a pragmatic expectancy of relatively short service lifetime of the constructions [6]. Permafrost was important for the foundation of buildings and large constructions.

When developing the coal mining industry in Svalbard in the early $20^{\text {th }}$ century, the first permanent settlements were established [7]. Buildings for different purposes, infrastructure supporting the coal-mining industry and other man-made structures are mostly wooden. Due to the lack of domestic timber, it is likely that the rot fungus arrived at the archipelago with the introduction of imported timber. The wooden cultural heritage remains at Svalbard has proven to degrade almost as rapid as on the mainland, despite the preservative benefits of permafrost. This is due to a combination of favourable microclimatic conditions and a species of wood-decaying fungi that thrives in Polar conditions [8].

However involuntary, the Polar and Svalbard have become laboratories for climate change. Nowhere else does global heating occur faster than in the Svalbard region [9]. Due to climate change, wooden structures at Svalbard are objective to a massive change in strain. At this, Svalbard serves as an important showcase for climate change, and for the whole world. In Longyearbyen, the capital of the Polar Archipelago, climate change is not a potential effect in the future, but an easily observed, ongoing process. The changes seen in both cultural heritage and modern wooden constructions at Svalbard serve as important information carriers, bearing witness of vital information about the development of fungal decay in wood as a result of ongoing climate change.

\subsection{Objectives}

The paper is written as part of the CULTCOAST project, funded by the Norwegian Research Council. It is based on CULTCOAST findings, and findings from preceding projects funded by the Svalbard environmental protection fund. Several field work registrations are displayed, over a time period of ten years: 1) the ongoing CULTCOAST project/CC (2019-2023), 2) the Permafrost and cultural heritage foundations' project/ PCHF (2014-17), 3) the Mining heritage in Longyearbyen project/MHL (2012-13) and, 4) the Managing rot damage in cultural monuments at Svalbard project/ROT (2009-10). A compilation of the findings with a final discussion and conclusion is presented.

The main objectives of this paper are to:

1) Determine causes of degradation in wooden cultural heritage structures in Polar areas;

2) Determine how climate and climate change impacts affect the fungal decay of wooden cultural heritage structures at Svalbard;
3) Display the necessity of physical measures in wooden cultural heritage structures in Svalbard.

The paper concludes on lessons learned, and how to transfer the knowledge value to both cultural heritage and modern structures in other climate zones and areas.

\subsection{Method}

Measurements from four different project in the period 2009 to 2019 are compiled, compared and discussed. In the different field works, wooden $\log$ foundations in cableway pylons and as piles under buildings where investigated. In addition, a literature study has been carried out. The different results of the four studies have been analysed separately, then compiled and discussed together, in context, and towards relevant research publications (both grey and published literature).

The following measurements were made at wooden building foundations and cable way pylons:

In the PCHF project:

- Present value and long-term measurements of the temperature at the surface and at three different depths in the ground (measured from the surface); Present value and relative moisture in the surface and in the ground alongside cultural heritage structures; The depth of the thawing zone, down to permafrost in areas alongside and under cultural heritage structures, and some distance away from such structures (control value).

In the MHL project:

- Drilling in twenty-five of the cableway pylons (four legged, all legs drilled with Densitomat decay detecting drill Resistograph E300/E400); Extraction of 125 wood samples from 34 cableway pylons for microscopic analysis for rot fungal species determination.

The following measurements were taken from wooden cladding, roofing panels and load bearing structures:

In the ROT project:

- Extraction of 187 wood core and -surface samples from 30 cultural heritage buildings for microscopic analysis for rot fungal species determination; Measurements of moisture content levels (\%) within the wood (with Protimeter MMS/AB-Wood Moisturemeter); Measurements of moisture levels (RH) and air temperatures in- and outside the building (with Protimeter MMS/Hygropalm).

The following examinations were performed of buildings and/or cable way pylons.

In all the case projects:

- Visual condition and consequence analyses, and evaluation of fungal decay situation.

The following technical terminologies are used: - Biodeterioration: Deterioration of organic material; - Fungal decay: Biodeterioration caused by fungi.

\section{Background}

\subsection{Cultural heritage at Svalbard}

In addition to residential, public and coal-mine related buildings the Svalbard archipelago holds more than 400 historical huts $[10,11,12]$. The natural and cultural 
heritage in Svalbard are of international significance and value, and Norway has a special responsibility to preserve it $[13,14,15]$. Svalbard was international common grounds until 1925 when it became part of Norway. The cultural sites and monuments are however regarded as international heritage. All man-made structures and sites at Svalbard dating before 1946, are protected by law and considered cultural heritage [16]. There are more than 2000 historic sites spread around the archipelago [6, 10]. Many of the sites consist of buildings and large mining constructions, of which almost all are wooden [7, 10, 17].

\subsection{Present climate and climate change impacts at Svalbard}

The present Polar climate in Svalbard is characterized by low average temperatures, permafrost, and limited precipitation. Climate scientists have calculated the following changes for Svalbard from 1971-2000 to 20712100 for medium to high scenarios for future greenhouse gas emissions, see Table. 1.

Table 1. Calculated changes in temperature, precipitation and permafrost. Source [9]

\begin{tabular}{|l|l|}
\hline $\begin{array}{l}\text { Climate indicator: } \\
\text { Instrumental period 1971- } \\
\text { 2000: }\end{array}$ & Climate change impacts: \\
\hline $\begin{array}{l}\text { Annual mean temperature } \\
\text { 1971-2000: }-5,9^{\circ} \mathrm{C}\end{array}$ & $\begin{array}{l}\text { Will increase. Ensemble } \\
\text { median about } 10^{\circ} \mathrm{C} \text { for high } \\
\text { and } 7^{\circ} \mathrm{C} \text { for medium } \\
\text { emissions }\end{array}$ \\
\hline $\begin{array}{l}\text { Annual mean precipitation } \\
\text { 1971-2000: } 196 \mathrm{~mm}\end{array}$ & $\begin{array}{l}\text { Will increase. Ensemble } \\
\text { median increase about } 65 \\
\% \text { for high and 45 \% for } \\
\text { medium emissions }\end{array}$ \\
\hline $\begin{array}{l}\text { Permafrost } \\
\text { Mean active layer thickness: } \\
\text { 100-200 cm (min/max 49- } \\
\text { 300) }\end{array}$ & $\begin{array}{l}\text { Heated all over Svalbard. } \\
\text { in coastal and low-lying } \\
\text { areas, for high emissions }\end{array}$ \\
\hline
\end{tabular}

Since 1961, the increase in temperatures at Svalbard (latitude $74-80^{\circ} \mathrm{N}$ ) has been three times higher than in Oslo (latitude $60^{\circ} \mathrm{N}$ ), and six times higher than global warming.

Measurement from the two instrumental periods 1961 1990 to $1971-2000$ indicate that the increases in temperatures have been considerably larger during winter than during summer, thus the differences between winter and summer temperatures have decreased slightly [9]. Fungal decay plays a major role in the degradation processes of built environments, including historic structures. Predicted climate change effects will make conditions more favourable for fungal decay, thus degradation processes are anticipated to increase in both number and severity. As the favourable ecological conditions vary in short distances, the microclimate is of great importance for the wood-decaying fungi [18].

\section{3 \\ Permafrost changes and impacts on built structures}

In Longyearbyen, climate change is not a distant, futuristic threat, but witnessed daily by the residents. The permafrost, which once provided a stable foundation for houses and roads, has begun to thaw. This leads to destabilization of exposed buildings and other structures. Almost all the buildings at Svalbard are founded on wooden logs piled into the permafrost, also many cultural heritage structures, like the cable way pylons in Longyearbyen. Roads, bridges, airports, and other infrastructure are also founded within the permafrost. The heating and thawing of the permafrost will likely, in the long run, affect the infrastructure through destabilization and fungal decay.

The permafrost is decisive in stabilizing the steep hills and mountains. Deep thawing of the permafrost will add to the destabilizing of the mountain sides. The thickness of the active layer increases over time, as a direct consequence of warmer summers. Increased landslide risks and erosion in coastal areas, and changes in the landscape, are among the consequences.

Monitoring of changes in permafrost has been subject to increasing interest the last years, within international climate research. At Svalbard, the results of such monitoring are reported to the Environmental monitoring of Svalbard and Jan Mayen (MOSJ). These registrations started in 1998. According to MOSJ [19], analyses indicate a temperature rise in upper parts of the permafrost at an average of $0.8^{\circ} \mathrm{C}$ per decade, at an accelerating speed for the last decade. As long as the monitoring has lasted, increasing temperatures have been registered as far down in the permafrost as to 80 metres depth [20]. The active layer has, in average, become 25 to $30 \mathrm{~cm}$ thicker since 1998, caused by increasing air temperatures the last decades $[19,20]$.

Due to climate change, the permafrost at Svalbard is heated at a faster pace than ever. Measurements clearly demonstrate how the steadily peaking air temperatures affect the permafrost. MET reports that by the end of 2019 the annual mean temperature, for 31 years in a row, exceeded the temperature normal [20]. Never before has such a high heating and thawing of the permafrost been measured. Several studies are linked to permafrost research in the Arctic and at Svalbard [21-27].

\subsection{Physical conditions for fungal growth}

Climate change impacts influence temperatures and moisture levels in wood and increase the risks for fungal decay [8]. Traditionally it has been assumed that the risk and rate of biodeterioration of externally exposed wood is correlated with overall climatic conditions. This has in later years been used to calculate the risk of fungal decay in Norwegian conditions, both with current climatic conditions and a predicted future climate scenario as shown in figures $2[28,29]$. 

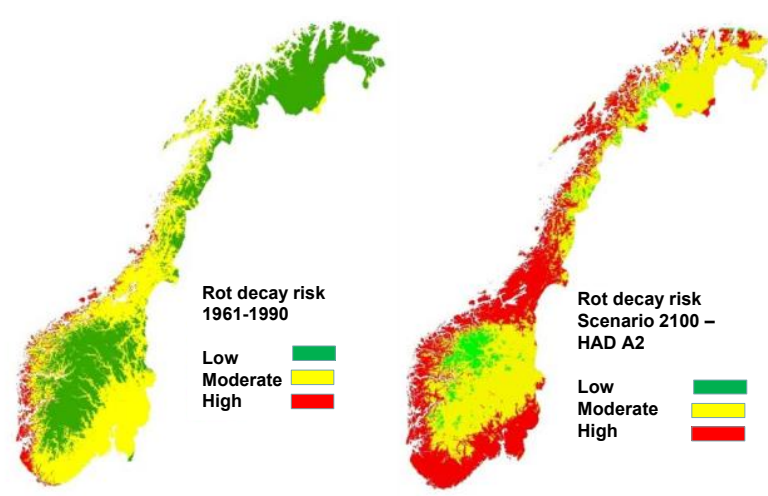

Fig. 2. Illustration of a calculated risk of decay in externally exposed wood. Left: Areas on mainland Norway, where fungal decay risk earlier has not been severe. The map displays the fungal decay risk situation in the instrumental period 1961-90. Right: Areas on mainland Norway that might become highly exposed to such risks within the next 50 to 100 years. The map displays a possible situation in a HAD A2 emission scenario for 2100. High rot decay risk is seen in the darkest shade [28].

The maps in fig. 2 give a somewhat impartial piece of the picture but yield a broad and upscaled impression of possible climate change impacts. However, in a pedagogic way the figures express a possible development of the rot decay risk trend over an alarmingly short period of time.

Whole buildings, and most building materials, are assumed to have a long life. To achieve this, we strive to build and use buildings in such a way that no harmful moisture load is created [31]. Dry conditions for wood constructions, and low values of relative humidity, provides poor growth conditions for mould and wooddecaying fungi. A relative humidity $(\mathrm{RH})$ of $75 \%$ is in general considered to be the critical limit for the growth of wood decaying fungi [32]. Wood-decaying fungi are well-developed to utilize nutrients in the wood. Because the ecological conditions can vary greatly in short distances, the microclimate is of great importance for the wood-decaying fungi [18]. Many factors need to be present for fungi to be established and grow in wood. Three very important factors are access to water, nutrition (here: woodwork) and favourable temperature, see fig. 3. In addition, how long these factors are available, is essential for growth [33]. At conditions drier than critical moisture content for wood-decaying fungi, growth will stop and eventually the fungi will die.

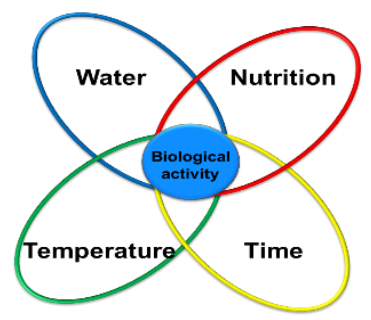

Fig. 3. Prerequisite conditions for wood-decaying fungi. Figure: Mycoteam/J. Mattsson

Several fungal species may survive prolonged drought for several years and continue the growth by a new moisturization. Similarly, growth can be inhibited at too high moisture levels. Low temperatures reduce the fungal activity, and cause hibernation. Some fungi can survive temperatures up to $75^{\circ} \mathrm{C}$, but most die at around $40-45^{\circ} \mathrm{C}$. The minimum temperature for growth of wood-decaying fungi is just above the freezing point, but then the activity is low [33].

\section{Findings: Wood deterioration}

\subsection{Fungal growth at Svalbard}

Growth conditions for wood-decaying fungi are strongly limited in the wooden pylons. Below the soil surface, accessible water and suitable temperatures for fungal decay only appear in the upper part of the thawing zone. Above the soil surface, accessible water is limited due to wind as a drying factor, even if the temperature is suitable for fungal growth.

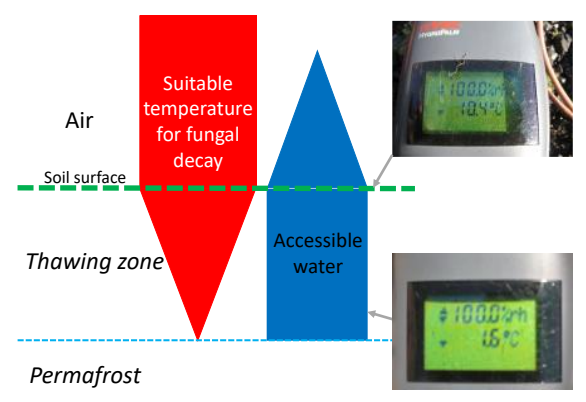

Fig. 4. Microclimatic conditions in wooden pylons, from the permafrost up to the air above soil surface. Modified from [17]

Wood in contact with soil have more favourable growth conditions for fungi, through accessing moisture from wet soil in the thaw zone, and because sun radiation induces higher temperatures locally on the soil surfaces (fig. 4). Fungal decay in lower parts of load-bearing timber piles is fatal for the stability of constructions, technical structures, or buildings (fig. 5).

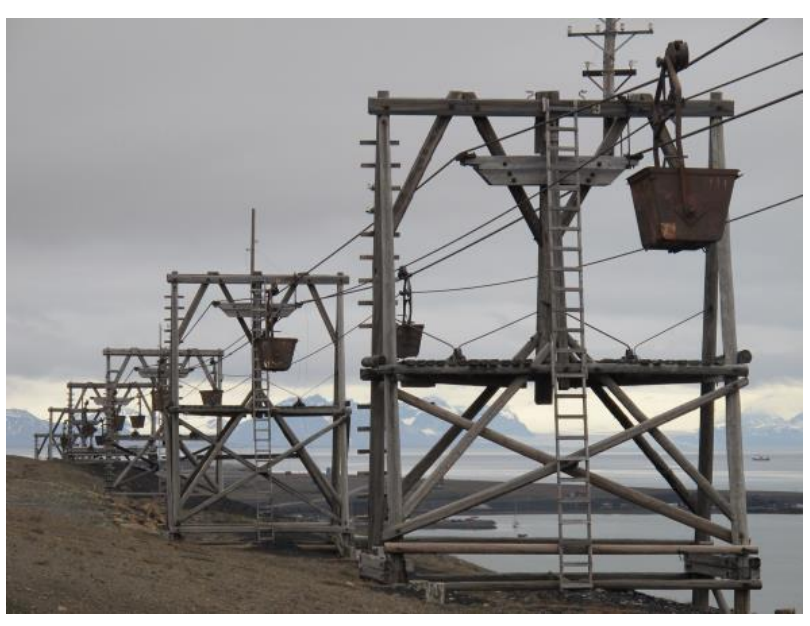

Fig. 5. Wooden structures with high risk of fungal decay where the wooden pylons are in contact with soil. Photo: Mycoteam/J. Mattsson

Our measurements demonstrated that temperature and moister content was favourable for fungal growth with 
higher risks of biodeterioration in the parts of the wooden materials in soil contact. Lack of well-documented and research based 'best practice' guidelines have in extreme cases resulted in loss of important cultural heritage constructions [34], due to the misconception that damage was not caused by rot fungi. Recently, the Governor of Svalbard has identified 'knowledge of degradation mechanisms and suitable measures' as one of the largest knowledge gaps for cultural heritage management in Svalbard [35].

\subsection{Fungal decay}

In temperate environments, the growing conditions for fungal decay are by and large favourable, both in wood with soil contact and above ground. In Polar areas, the growth is limited, due to longer periods with degrees below freezing point and little precipitation. Thus, only smaller parts of wood risk development of fungal decay.

Until the beginning of this century, it was a general perception that the conditions at Svalbard were too rough and cold for rot fungus to thrive, and that the permafrost perpetually preserved and protected the wooden foundations [34]. Thus, there has been a considerable lack of understanding of how biodeterioration in general, and fungal decay in specific, affect the wooden constructions [34]. Due to the assumed low fungal decay risk in the cold climate, wooden houses in Svalbard have been founded on wooden poles into the permafrost, or

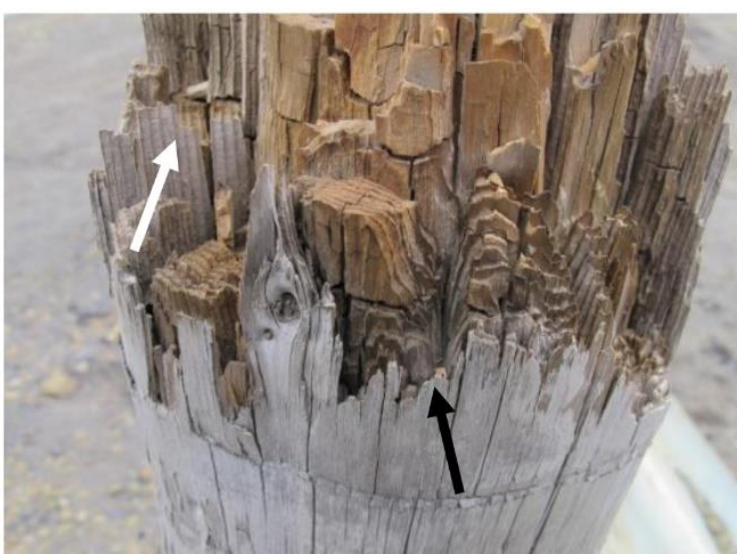

Fig. 6. Typical pattern of decay in wooden piles at Svalbard: an unharmed outer layer of 4-5 mm, and extensive deterioration in the internal part [37]. Photo: Mycoteam/J. Mattsson

directly on the ground. However, both international and national findings reveal significant biodeterioration in Polar environments [8, 30, 36-42]. Some rot fungi, such as the most active rot fungus in the historic structures at Svalbard, have adapted to living in cool environments, with optimized growth around $5-15^{\circ} \mathrm{C}$. The microscopic analysis for rot fungal species determination in the ROTproject proved that the most common rot fungus at Svalbard is Leucogyrophana mollis, causing brown rot [8]. In wooden logs piled into the permafrost, L. mollis has special damage characteristics: The rot fungus is hardly ever visible on the wood surface. The degradation occurs directly beneath the surface, where extensive damage may be found, see fig. 6,7 , and 8 . The damages usually extend to $12-30 \mathrm{~cm}$ above ground, and correspondingly $10-15 \mathrm{~cm}$ below the ground surface. The wood is heavily degraded from the inside and out, and the distance between the surface of fresh wood and established damage may often be only a few millimetres [33], as shown in fig. 6, 7, and 8. On the mainland, however, degradation caused by L. mollis appears more commonly on the outside of similar pylons [37].
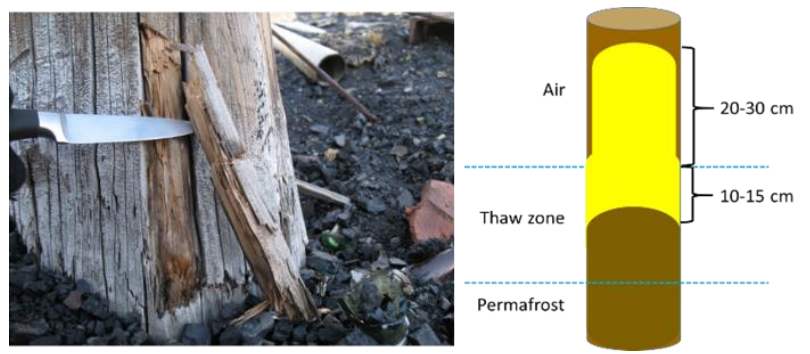

Fig. 7. On Svalbard, fungal decay is commonly found inside the wooden piles which are in contact with soil. Brown: sound wood. Yellow: decayed wood. Modified from [17]

Many of the 209 cableway pylons in Longyearbyen and Hiorthhamn (built 1937-1968) had collapsed. 59 pylons were investigated, six of these had collapsed (date of collapse was known, the ROT and MHL projects) [30, $38]$. When the old cableway pylons from the 1930's needed repairing (presumably in the 1970's), creosoted wood was employed to substitute the whole pylons (due to ongoing mining activities). In the treated wood, no fungal decay was found in 2013 (the MHL project). [38].

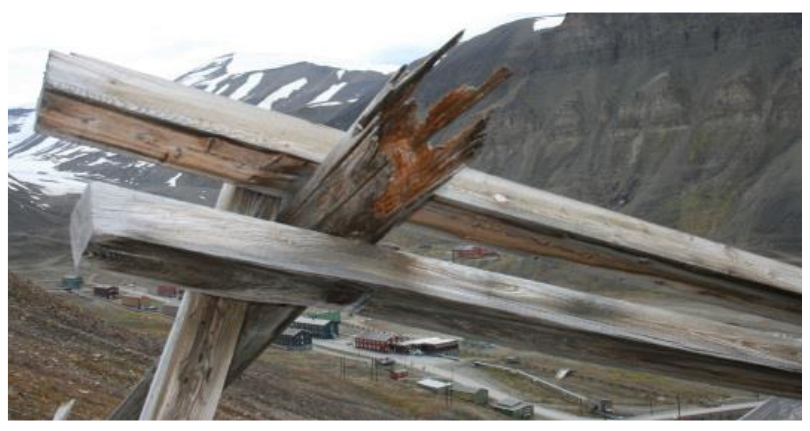

Fig. 8. Characteristic pattern of extensive, internal fungal decay in wood with soil contact at Longyearbyen, Svalbard. The external layer of wood is undamaged, whilst the inner parts are heavily decomposed. Photo: NIKU v/A.C. Flyen.

\section{Discussion}

A series of factors affect the service lifetime of wooden products and constructions. The two main external factors are moisture and temperature. Other important influences are the area of application, the natural resilience and durability of the material, wood preservation processes, occurrence of wood decaying substances, architecture and solutions, and craftmanship quality [29, 34, 39].

The founding logs of the cable-way pylons were relatively early objected to fungal attacks, inside the pylons just above and beneath the ground surface. This was found also in quite new wooden building foundations. 
The expanding damages may be difficult to detect without thorough technical examinations, due to internal growth.

Knowledge on how permafrost affects wooden logs, is limited, mainly linked to refreezing of soil after interventions. Important issues are: the depth of thawing beneath the intervention, and; time span to re-establish and normalize the permafrost after an intervention, if at all. Also, to what degree will climate change further impact on the re-freezing. Testing and discussions about other foundation methods for new buildings in Polar settlements are currently being carried out.

Our measurements indicate clear patterns, with relatively favourable fungal growth conditions in wood situated within the active permafrost layer. The extent of fungal decay is expected to increase due to different aspects: 1) many of the old buildings already have fungal decay damages. Once initiated, fungal decay may increase, and; 2) climate change impacts may further increase the length of the annual degradation period. The decay develops inside wooden materials and may be difficult to detect [37]. The ROT and MHL-projects [8, $38,40,41]$ found that the massive wooden cableway pylons collapse after an average of 70 years, due to degradation. Fungal decay has also been detected in other wooden construction elements above ground, but to a far less extent than at the Norwegian mainland, due to less favourable in-situ microclimates for fungal growth [18, $34,42]$. There, such damages are not dominated by $L$. mollis. but rather by other, more aggressive fungal species [37].

A general assumption that the risk and rate of biodeterioration of externally exposed wood is correlated with overall climatic conditions, does not coincide with our findings, indicating that fungal deterioration is related to the microclimatic conditions rather than the overall conditions. Thus, it will be difficult to base local scenario calculations of risk of fungal decay on general information on temperature and moisture levels. This substantiates the outspoken difficulties in specific, scenario-based predictions of impacts of climate change at local and micro-local levels. Our findings support Mattsson [37], that it is the microclimatic rather than the macroclimatic conditions that first and foremost predicts fungal growth and decay. In addition to microclimatic effects, macroclimatic conditions will affect the microclimatic developments. This influence is however difficult to predict, and the development will obviously have huge effects on our wooden cultural heritage.

Recent research has shown that overall modelling, like the climate index, does not reflect the actual risk for biodeterioration on different parts of a building [37, 39]. Since the risk for biodeterioration is mainly correlated with the local conditions regarding actual moisture and temperature, the local knowledge of climate change is of essential importance for understanding and prediction of future damages. Even if it is not possible to use overall modelling for prediction of future risk for biodeterioration, it is no doubt that risk for increased fungal deterioration will increase in the decades to come. Due to patterns of climate change, it is expected that the increase of fungal decay will occur increasingly faster in Polar areas than in mainland Norway.
In all four case projects (CC, PCHF, MHL and ROT), we have demonstrated a strong and relatively

rapid degradation of the wood in the cableway pylons and wooden building foundations in soil contact. The findings indicate that such a strong degradation will increase. The active layer of the permafrost poses a serious problem for preservation of wooden structures in contact with the soil. Despite the cold and dry polar climate, significant rot damage has occurred in many of the wooden historic structures during the 20th century. The short summer season has provided conditions in the active layer leading to microclimatic conditions that are favourable for rot fungi in areas just above and beneath the ground. The air temperature raise at Svalbard leads to increasing depth in the active layer and to increasing temperatures in the soil.

\section{Conclusion}

Recent and ongoing international permafrost research is rather extensive. Specific knowledge on local ground and permafrost conditions concerning wooden logs founded in the permafrost, is generally lacking. Such knowledge is however fundamental in addressing the climate change impacts and fungal decay in vulnerable historic structures at Svalbard. The main objectives are directing these aspects. Main conclusions are:

\section{1) Determine causes of degradation:}

- The Svalbard climate is relatively favourable for fungal growth in wood just above and below soil surface;

- Microclimatic conditions predict fungal growth and decay; macroclimatic conditions affect the microclimatic developments; climate change impact on microclimatic conditions and will thus have huge effects on our wooden cultural heritage;

- Lack of specific knowledge, too low consciousness on fungal related damages, and lack of monitoring and maintenance, are some reasons for damage development and dispersion;

- Wrong choices of detail solutions, incorrect design and execution of construction, open for fungal decay.

2) Determine how climate and climate change impacts affect the fungal decay:

- The extent of fungal decay is expected to increase due to climate change impacts;

- Accordingly, this will happen increasingly faster in the High Arctic than in mainland Norway;

- If not attended to, fungal decay related problems will increase, regardless of climate change;

- Decay in wooden constructions above ground may gain increased foothold due to climate change impacts.

3) Display the necessity of physical measures: - To avoid collapse of buildings and pylons, reparations are needed, due to severe fungal degradation;

- Impacts of thawing permafrost on wooden logs in High Arctic areas must be further elucidated, to develop climate change adapted repair- and restoration methods.

- In extreme cases, lack of well-documented and researchbased guidelines have led to loss of important cultural heritage constructions;

- In order to achieve an optimum service life of the founding wooden piles, a monitoring program following 
further development of climate conditions, and associated effects, will be optimal.

- The permafrost has difficulties in re-establishing after interventions when replacing wooden piles, leading to unstable conditions for the cableway pylons and increased fungal growth in the active layer.

- Knowledge on how climate change will impact on the re-freezing rate of the permafrost after interventions is lacking and needs to be further investigated.

Biodegradation of wood occurs almost as fast in Svalbard as in mainland Norway, and one species of rot fungus has specialized to thrive in Polar climate. The damages to wood foundations deposited in the permafrost occurs in the transition between soil and air, as well as some decimetres above and below this point. With increasing temperatures and precipitation, degradation will increase in these areas.

Through investigations of established fungal decay, we have established that the actual damages correlate well with the physical conditions in the ground. The consequence is a damage picture characteristic for wood in contact with soil in the active permafrost layer. There is no imminent danger for biodeterioration for wood founded in solid permafrost, unless the active layer increases in thickness. According to measurements, this is alas already occurring, and will most probably increase. Few conducted studies are related to cultural historic structures and permafrost related questions.

The deduction that certain microclimates also in Polar areas are favourable to fungal growth and decay, is a known fact. What is alarming, are the probable enhancing effects of climate change. We claim that with extended knowledge on how climate change may affect natural development of fungal decay, such negative impacts may be reduced. Further, due to the complexity of fungal growth and wooden decay in general, and the displayed knowledge on such degradation in Polar areas in specific, the impacts of climate change may not be generalized in order to predict the effects in building materials. Another approach is required.

We conclude that degradation of wood in the high Arctic region will become more severe. Because it is impossible to predict a general pattern for future degradation, a practical approach is needed. Focusing on delaying fungal growth and degradation on/in existing wooden constructions while repairing damages, and proactive measures to limit damages, are important efforts. More knowledge and experience exchange between cultural heritage management and new technological development initiatives is needed. In addition, further research on the protection of cultural heritage from fungal attacks, increasing fungal degradation, and the destabilization due to permafrost thawing, is imperative.

\section{Research relevance and transfer value - lessons learned}

The case of Svalbard is special. Cultural and historical remains are seldom in ordinary use, but rather traces of earlier human activity giving depth and explaining the human dimensions in the open arctic landscape. The cultural history is young, dating back to 1596 , so is the cultural heritage. The climate is characterized by low average temperatures, permafrost, and limited precipitation, and the patterns of fungal decay is significantly different from that of mainland Norway. However, there are similarities with the mainland, and the lessons learned from these Polar areas might add longevity and sustainability to wooden cultural heritage constructions also in different areas and environments. The ROT and MHL projects have demonstrated that biodegradation of wood occurs almost as fast in Svalbard as in mainland Norway. Thus, indicators for decomposition of wood in structures on Svalbard could be transferable to other places. Knowledge on how climate change may affect the evolution of fungal decay and degradation is valuable, and transferable to other settings.

We would like to thank the Research Council of Norway and Svalbard Environmental Protection Fund for financial support, and the Mycological laboratory at Mycoteam for support with analyses of all samples.

\section{References}

1. United Nations, The 2030 Agenda for Sustainable Development, (2015) https://sustainabledevelopment.un.org/?menu=130

2. P. Aune, Wooden constructions (in Norwegian) (1992)

3. D. Kittang, R. Narvestad, A.Q. Nyrud, Wood in the City - an overview of knowledge (Norw.) Projekt report (2011)

4. H. Callum, K. Zimmer, The environmental impacts of wood compared to other building materials, (2018)

5. G. Alfredsen, B.R. Asbjørnsen, P.O. Flæte, E. Larnøy, Environmental effects of using wood Compilation of knowledge on wood and wood products (Norw.) (2008)

6. K. Dahle, H.B. Bjerck, K. Prestvold, Cultural heritage plan for Svalbard 2000 - 2010 (Norw.) (2000)

7. T.B. Arlov, History of Svalbard (Norw.) (2003)

8. J. Mattsson, A.C. Flyen, M. Nunez, Wood-decaying fungi in listed buildings and structures on Svalbard. Agarica 29, 5 - 14. (2010)

9. I.Hanssen-Bauer, E.J.Førland, H.Hisdal, S.Mayer, A.B.Sandø, A.Sorteberg (ed), Climate in Svalbard 2100 - a knowledge base for climate adaptation. The Norwegian Centre for Climate Services (NCCS). NCCS report no. 1/2019 (2019)

10. I.S. Sandodden, H.T. Yri, H. Solli, Cultural heritage plan for Svalbard 2013 - 2023 (Norw.) (2013)

11. P.K. Reymert, O. Moen, Hunter cabins at Svalabrd 1794-2015 (Norw.) (2015)

12. Askeladden. The Directorate for Cultural Heritage official database of cultural monuments and sites (in Norwegian). Downloaded 15.01.2020 
13. Norwegian Ministry of Justice. White paper 9 (1999-2000). (2000)

14. Ministry of Justice and Public Security. White Paper 22 (2008-2009), Svalbard (2009)

15. Norwegian Ministry of Justice and Public Security. White Paper 32 (2015-2016). Svalbard (2016)

16. Ministry of Climate and Environment, Svalbard Encironmental Protection Act, of 15 June 2001

17. J. Mattsson, A.C. Flyen, Bio-deterioration in buildings in Svalbard. Hist. Polar Bases Preservation and Management. ICOMOS Monuments and sites 23-29 (2008)

18. L.R. Gobakken, J. Mattsson, G. Alfredsen, The importance of critical in-situ conditions for inservice performance of wood. Agarica, 34, 29-36 (2014)

19. MOSJ Environmental Monitoring of Svalbard and Jan Mayen. Downloaded 16.10.2020 http://www.mosj.no/no/klima/land/permafrost.html

20. Norwegian Meteorological Institute. Downloaded 16.01.2020. https://vimeo.com/383241800

21. O. Humlum, A. Instanes, J.L. Sollid, Permafrost in Svalbard: a review of research history, climatic background and engineering challenges, Polar Research, 22:2, 191-215 (2003)

22. J. Weismüller, U. Wollschläger, J. Boike, X. Pan, Q. $\mathrm{Yu}, \mathrm{K}$. Roth, Modeling the thermal dynamics of the active layer at two contrasting permafrost sites on Svalbard and on the Tibetan Plateau. The Cryosphere, 5, 741-757 (2011)

23. P. Dolnicki, M. Grabiec. D. Puczko, Ł. Gawor, T. Budzik, J. Klementowski, Variability of temperature and thickness of permafrost active layer at coastal sites of Svalbard. Polish Polar Research. 34/4, 353374 (2013)

24. I. Sobota, M. Nowak, Changes in the dynamics and thermal regime of the permafrost and active layer of the high arctic coastal area in north-west Spitsbergen, Svalbard. Geografiska Annaler. Series A, Physical Geography 96 227-240 (2014)

25. T. Watanabe, N. Matsuoka, H.H. Christiansen, S. Cable, Soil Physical and Environmental Conditions Controlling Patterned-Ground Variability at a Continuous Permafrost Site, Svalbard. Permafrost and Periglacial Processes 28/2 433-445 (2017)

26. M. Eckerstorfer, E. Malnes, H.H. Christiansen, Freeze/thaw conditions at periglacial landforms in Kapp Linné, Svalbard, investigated using field observations, in situ, and radar satellite monitoring. Geomorph. 293, 433-447 (2017)

27. SWIPA. Snow, Eater, Ice and Permafrost in the Arctic. AMAP (2017)

28. C. Flyen Øyen, A-J. Almås, O. Hygen, I. Sartori, Climate and vulnerability analysis (Norw.). Project report (2010)

29. K.R. Lisø and T. Kvande, Climate adaptation of buildings (Norw.) (2007)
30. A.C. Flyen, J. Mattsson, Permafrost and foundations for cultural heritage structures in Longyearbyen. (Norw.) (2017)

31. S. Geving, J.V. Thue, Moisture in buildings (Norw.) (2002)

32. H. Viitanen, Factors affecting the development of mould and brown rot decay in wooden structures. Effect of humidity, temperature and exposure time, $\mathrm{PhD}$ theses, SLU, Uppsala, Sweden (1996)

33. J. Mattsson, Fungal decay in buildings Occurrence, detection, assessment and repair (Norw.) (2010)

34. A.C. Flyen, J. Mattsson, Managing rot damage in cultural monuments on Svalbard. Causes of damage and methods of repair (Norw.) (2010)

35. Norwegian Polar Institute, Environmental management's research needs at Svalbard (Norw.) 2016)

36. R. Blanchette, B.W. Held, J.A. Jurgens, Northumberland House, Fort Conger and the Peary Huts in the Canadian High Arctic: Current condition and assessment of wood deterioration taking place. ICOMOS International Polar heritage Committee, 30-37. (2008)

37. J. Mattsson, The impact of microclimate on biodeterioration of wood in historic buildings. Doctoral theses at NTNU (2017)

38. A.C. Flyen, J. Mattsson, Mining heritage in Longyearbyen and Hiorthhamn. Protected cable cars: condition and conservation (Norw.) (2013)

39. C. Brischke, Potential impacts of climate change on wood deterioration. IWPJ 1(2) 85-92 (2010)

40. A.C. Flyen, Environmental monitoring of Cultural Heritage at Svalbard. Existing and past monitoring systems in Svalbard (Norw.) (2016)

41. J. Mattsson, A.C. Flyen, How can signs of biodeterioration save cultural heritage? Cultural heritage preservation, EWCHP-2012. Proceedings of the 2nd European Workshop on Cultural Heritage Preservation, Kjeller, Norway 2012. 20-26 (2012)

42. J. Mattsson, A.C. Flyen, Preventive methods against biodeterioration of protected building materials in Svalbard. Polar Settlements - Location, Techniques and Conservation. International Polar Heritage Committee of ICOMOS. 44-50 (2011). 